\title{
Glycerol Production in Subcutaneous Adipose Tissue in Lean and Obese Humans
}

\author{
Per-Anders Jansson, Annhild Larsson, * Ulf Smith, and Peter Lönnroth \\ Departments of Medicine II and ${ }^{*}$ Radiation Physics, University of Göteborg, Sahlgren's Hospital, S-413 45 Göteborg, Sweden
}

\begin{abstract}
To estimate the regional subcutaneous glycerol production rate in normal and obese humans, the venous arterialized plasma glycerol, interstitial glycerol in the subcutaneous adipose tissue together with adipose tissue blood flow (ATBF, $\mathrm{ml} / 100 \mathrm{~g} \cdot \mathrm{min})$ were measured in the postabsorptive state and for $2 \mathrm{~h}$ after ingestion of $100 \mathrm{~g}$ of oral glucose. Eight lean and eight obese men with normal oral glucose tolerance tests were investigated with the subcutaneous microdialysis technique and ${ }^{133} \mathrm{Xe}$ clearance. In the postabsorptive state, the interstitial glycerol concentrations in lean and obese subjects were $170 \pm 21$ vs. $282 \pm 28$ $\mu M(P<0.01)$ and $156 \pm 23$ vs. $225 \pm 12 \mu M(P<0.05)$ in the abdominal and femoral subcutaneous adipose tissue, respectively. The corresponding arterial glycerol levels were $54 \pm 4$ vs. $75 \pm 14 \mu \mathrm{M}$ (NS). Abdominal ATBF was greater in lean subjects (3.2 \pm 0.6 vs. $1.6 \pm 0.3 ; P<0.05)$, whereas femoral ATBF was similar in both groups $(2.7 \pm 0.4$ vs. $2.4 \pm 0.7)$. Estimated mean local glycerol release $(\mu \mathrm{mol} / 100 \mathrm{~g} \cdot \mathrm{min})$ was similar in the lean and obese group $(0.16 \pm 0.03$ vs. $0.20 \pm 0.05$ and $0.18 \pm 0.02$ vs. $0.17 \pm 0.04)$ in the abdominal and femoral site, respectively. We conclude that glycerol production from the subcutaneous tissue is increased in obesity, irrespective of adipose tissue distribution. This enhancement is due to the increased adipose tissue mass. (J. Clin. Invest. 1992. 89:16101617.) Key words: blood flow $\bullet$ glycerol $\bullet$ lipolysis $\bullet$ microdialysis • obesity
\end{abstract}

\section{Introduction}

It has been shown in several studies that obesity, particularly when combined with abdominal fat distribution, is associated with insulin resistance, hyperinsulinemia, and propensity for type II diabetes (1-3). Insulin resistance is also linked to hypertension and cardiovascular disease (4). Subjects with abdominal obesity also have a higher blood pressure (5) and a greater risk for cardiovascular disease $(6,7)$.

One possible mechanism for the insulin resistance in obesity is an increased lipolytic rate in the enlarged fat cells resulting in elevated turnover rates of free fatty acids (FFA) (8-10). Systemically elevated FFA levels may induce insulin resistance in both muscles and liver (11). Several studies with fat cells in vitro have shown that adipocytes from the abdominal region have a higher lipolytic rate than those from peripheral adipose tissue depots. This finding has been proposed as one factor of

Address reprint requests to Dr. Jansson, Department of Medicine II, Sahlgren's Hospital, S-413 45 Goteborg, Sweden.

Received for publication 10 September 1991 and in revised form 18 December 1991.

J. Clin. Invest.

(c) The American Society for Clinical Investigation, Inc.

0021-9738/92/05/1610/08 \$2.00

Volume 89, May 1992, 1610-1617 importance for the increased insulin resistance and morbidity in abdominal obesity (12). Visceral adipose tissue has the highest lipolytic activity (13). Elevated portal FFA levels may lead to both hepatic insulin resistance (14) and reduced insulin degradation by the liver $(15,16)$.

The regional differences in lipolytic rate found in vitro with isolated adipocytes as discussed above were recently confirmed in vivo where regional glycerol concentrations in the adipose tissue interstitial water were measured with the recently developed microdialysis technique $(17,18)$. Indirect estimations of FFA release from different regions are also in agreement with this concept (19). Owing to the newly developed calibration technique, microdialysis can now be used to measure in vivo the "true" glycerol level in the subcutaneous tissue water (20). However, the interstitial glycerol concentration may not directly correlate with the local glycerol release in different regions in that the blood flow may be a rate-limiting factor (21, 22). Furthermore, the blood flow may vary in different regions $(23,24)$. Therefore, we have combined the microdialysis method to determine the interstitial glycerol concentrations with ${ }^{133} \mathrm{Xe}$ clearance to measure the adipose tissue blood flow (ATBF). ${ }^{1}$ The studies were performed in both lean and obese subjects in the abdominal and femoral subcutaneous adipose tissue regions. The data show that glycerol release per tissue weight is similar in both groups and in both regions, whereas the glycerol release per cell is increased in the obese.

\section{Methods}

Subjects. Eight obese and eight lean male individuals of similar age and with normal glucose tolerance according to the criteria of the National Diabetes Data Group (25) participated in the study. The clinical characteristics of the subjects are shown in Table I. All subjects were without regular medication and had been weight-stable for at least 3 mo before the study. The participants were asked to maintain their regular dietary habits and physical activity and to consume no alcohol $3 \mathrm{~d}$ before the investigation. Smoking was not allowed $1 \mathrm{~d}$ before the study. The volunteers gave their informed consent and the study was approved by the Radiation Safety Committee as well as the Ethical Committee of the University of Göteborg.

Study protocol. The subjects had fasted overnight and arrived at the laboratory at 8 a.m. Room temperature was kept at $26^{\circ} \mathrm{C}$. The subjects were investigated in the supine position. A polyethylene catheter was placed in a dorsal hand vein for blood sampling. The forearm was warmed with heating pads $\left(60-70^{\circ} \mathrm{C}\right)$; this step results in arterialized venous blood with the $\mathrm{O}_{2}$ saturation $93 \pm 1 \%$ (26). Control experiments showed that the heating pads did not change the microdialysis results or the ATBF in either the abdominal or the femoral region (not shown).

Microdialysis catheters $(30 \times 0.3 \mathrm{~mm}, 3,000$-mol wt cutoff, Cuprophan B4 AH, Cobe Corp., Denver, $\mathrm{CO}$ ) were placed in the left abdominal subcutaneous tissue, $5 \mathrm{~cm}$ lateral to the umbilicus, and in the right femoral subcutaneous tissue, one third of the distance between the patella and the superior anterior iliac spine. The nylon tubing inlet of the microdialysis catheter was connected to a microinjection pump

1. Abbreviations used in this paper: ATBF, adipose tissue blood flow; OGTT, oral glucose tolerance test. 
Table I. Clinical Characteristics of the Lean and Obese Individuals

\begin{tabular}{|c|c|c|c|c|c|c|c|}
\hline & Age & $\begin{array}{c}\text { Body } \\
\text { weight }\end{array}$ & $\begin{array}{l}\text { Body } \\
\text { fat }\end{array}$ & $\begin{array}{l}\text { Body mass } \\
\text { index }\end{array}$ & $\begin{array}{l}\text { Waist/hip } \\
\text { circumference } \\
\text { ratio }\end{array}$ & $\begin{array}{l}\text { Fasting } \\
\text { glucose }\end{array}$ & $\begin{array}{l}\text { Fasting } \\
\text { insulin }\end{array}$ \\
\hline & $y r$ & $k g$ & $k g$ & $\mathrm{~kg} / \mathrm{m}^{2}$ & & $\mathrm{mmol} / \mathrm{liter}$ & $m U /$ liter \\
\hline Lean & $28 \pm 1$ & $79 \pm 3$ & $10 \pm 1$ & $21.9 \pm 0.4$ & $0.86 \pm 0.02$ & $4.8 \pm 0.1$ & $5 \pm 1$ \\
\hline Obese & $30 \pm 2$ & $130 \pm 8$ & $46 \pm 7$ & $39.3 \pm 2.2$ & $1.06 \pm 0.02$ & $4.7 \pm 0.2$ & $13 \pm 2$ \\
\hline$P$ level & NS & $<0.001$ & $<0.001$ & $<0.001$ & $<0.001$ & NS & $<0.05$ \\
\hline
\end{tabular}

Data shown are means $\pm \mathrm{SE}$.

(Carnegie Medicine, Stockholm, Sweden), and saline with $2.5 \mathrm{mM}$ glucose added (to prevent deprivation of interstitial glucose [20, 27]) perfused the system at a rate of $2.5 \mu \mathrm{l} / \mathrm{min}$. After $60 \mathrm{~min}$ of equilibration, the dialysate was collected in 10-min intervals from the outlet of the tubing. A maximum delay of $12 \mathrm{~min}$ was expected between an ongoing change in the surrounding extracellular water and the dialysate for glycerol when samples were collected every $10 \mathrm{~min}$ (17).

The calibration procedure for each catheter was essentially performed as in previous studies $(17,20)$. Briefly, five different concentrations of glycerol $(0-300 \mu \mathrm{M})$ were added to the perfusate and the net change of the metabolite concentration in the dialysate was recorded (metabolite $_{\text {out }}-$ metabolite $_{\text {in }}=$ net change). The order of the glycerol concentrations in the perfusate was arranged to avoid alterations of the intercellular glycerol concentration before the oral glucose tolerance test (OGTT). Thus, $30 \mathrm{~min}$ of perfusion with $50 \mu \mathrm{M}$ glycerol added to the perfusate preceded the OGTT. The finding that the relationship between the glycerol concentration in the perfusate and the net increase of glycerol after dialysis was strictly linear shows that the intercellular glycerol concentration was not changed during calibration procedure. Regression analysis was used to calculate the interstitial concentration and the percent recovery of glycerol from the interstitial fluid to the dialysate. During the calibration period which persisted for $\sim 5 \mathrm{~h}$, there was a highly significant linear correlation between glycerol concentration in the perfusate and net change in the dialysate. Mean recovery of interstitial glycerol in the dialysate was $29 \pm 3 \%(n=32)$.

At around 1 p.m. each subject ingested $100 \mathrm{~g}$ of glucose dissolved in $\sim 250 \mathrm{ml}$ of lemon flavored tap water. Blood samples were drawn just before the glucose load and metabolite levels in the subcutaneous tissue and arterialized venous plasma were followed for $2 \mathrm{~h}$. The samples were kept on ice and immediately centrifuged $\left(3,000 \mathrm{~g},+4^{\circ} \mathrm{C}\right)$. Blood plasma and dialysate supernatant were collected and stored at $-20^{\circ} \mathrm{C}$ until analyzed.

Each study was terminated by aspirating fat biopsies in local anesthesia (Carbocain, Astra, Södertälje, Sweden) from the microdialysis sites. Mean fat cell size and fat cell number per kilogram adipose tissue were estimated as previously described (28). Body fat was estimated by impedance (29), and skin temperature was measured at both tissue regions in all subjects with an electric thermometer (type DU-3, Ellab A/S, Copenhagen).

Blood flow measurements. ATBF was measured by the ${ }^{133} \mathrm{Xe}-$ washout method (30). Briefly, 6-9 MBq of ${ }^{133} \mathrm{Xe}$ (Mallinckrodt, Petten, The Netherlands) in $0.1 \mathrm{ml}$ of sterile saline was injected into the subcutaneous adipose tissue contralateral to the microdialyzing sites. The depot was injected slowly over a 2-min period at least $5 \mathrm{~mm}$ under the skin with a special injection device kept at an angle of $45^{\circ}$, about 60 min before the radioactivity was measured. Disappearance of ${ }^{133} \mathrm{Xe}$ was monitored continuously with a $2 \times 2$-in $\mathrm{NaI}(\mathrm{Tl})$ detector (Canberra Industries, Inc., Meriden, CT) covered by a cylindrical collimator and coupled to a multichannel analyzer (ND 62, Nuclear Data, Schaumburg, IL). In order not to interfere with the counting geometry the detector was placed $30-50 \mathrm{~cm}$ from the ${ }^{133} \mathrm{Xe}$ depot. Only an energy interval corresponding to the photopeak of $81 \mathrm{keV}$ was registered, and the initial counting rate ranged from $5 \times 10^{4}$ to $10^{5} \mathrm{cpm}$ enabling reliable measurements for at least 3-4 h. Counts were accumulated during consecutive 60-s intervals and plotted on a logarithmic-linear diagram as function of time. Subcutaneous adipose tissue blood flow was then calculated as: ATBF $=k \cdot \lambda \cdot 100(\mathrm{ml} / 100 \mathrm{~g} \cdot \mathrm{min})$, where $\lambda$ is the tissue to blood partition coefficient for ${ }^{133} \mathrm{Xe}$ at equilibrium, and $k$ is the rate constant of the washout curve. A straight line was fitted through the experimental points in the logarithmic-linear diagram. Experimental values of $k$ were estimated as: $\left(\ln y_{1}-\ln y_{2}\right) \cdot T^{-1}$, where $y_{1}$ and $y_{2}$ are the counting rates at two occasions and $T$ is time in minutes between these registrations. The time interval between two registrations was at least $25 \mathrm{~min}$. A mean value of $10.0(\mathrm{ml} / \mathrm{g})$ was used for the partition coefficient. This value was considered constant during the investigation (30). No corrections for hematocrit, plasma proteins, and lipids were performed.

Chemical analyses. Glycerol levels were analyzed by measuring the incorporation of ${ }^{32} \mathrm{P}$ from $\left[\gamma-{ }^{32} \mathrm{P}\right] \mathrm{ATP}$ in the presence of glycerol kinase as described by Bradley and Kaslow (31). Enzymatic methods were used to estimate glucose (Merck, Darmstadt, FRG) and FFA (Wako Chemicals, Neuss, FRG). Insulin analyses were performed with a radioimmunoassay method (Pharmacia, Uppsala, Sweden).

Calculations. Control experiments in which ${ }^{133} \mathrm{Xe}$ was injected in the site of the microdialysis catheter have shown that the ATBF near the catheter was similar to that of other adipose tissue regions (data not shown). Therefore, Fick's principle could be used to estimate the regional rate of glycerol release. Arterialized venous plasma $(A)$ and venous plasma concentrations of glycerol $(V)$ and plasma flow rate $(Q)$ were entered into the formula: $(V-A) \cdot Q \cdot\left(1\right.$-hematocrit $\left.10^{-2}\right)(\mu \mathrm{mol} /$ $100 \mathrm{~g} \cdot \min )$. Recalculation of interstitial $(I)$ to venous $(V)$ glycerol levels was performed by the equation: $V=(I-A) \cdot\left(1-e^{-P S / Q}\right)+A$, where $P S$ is the permeability surface product area for glycerol (approximated to be $\sim 5 \mathrm{ml} / 100 \mathrm{~g} \cdot \min )(32,33)$.

Statistical analyses. Regression analyses were performed with the least squares method and linear correlations were tested using Pearson's correlation coefficient. Student's two-tailed $t$ test was used for paired and unpaired data. A linear nonparametric permutation test was applied for paired comparisons of blood flow and glycerol production (34).

\section{Results}

Fasting blood and tissue levels. In the postabsorptive state the mean blood glucose level was similar in the two subject groups, whereas the mean plasma insulin level was higher in the obese group (Table I). Mean body fat mass was $10 \pm 1$ and $46 \pm 7 \mathrm{~kg}$ (mean \pm SE) $(P<0.001)$ in the lean and obese groups, respectively (Table I). Mean fat cell size was increased in the femoral compared to the abdominal site $(P<0.05)$ in the lean subjects. Fat cell diameters were increased in both regions in the obese group (Table II).

Table III shows subcutaneous interstitial and plasma glycerol levels in the two groups. Interstitial glycerol was significantly higher (approximately three- to fourfold increase, $P$ 
Table II. Fat Cell Sizes of the Subcutaneous Regions in the Lean and Obese Individuals

\begin{tabular}{|c|c|c|c|c|c|c|}
\hline & $\begin{array}{l}\text { Mean fat cell } \\
\text { size, abdominal } \\
\text { region }\end{array}$ & $\begin{array}{l}\text { Mean fat cell } \\
\text { size, femoral } \\
\text { region }\end{array}$ & $\underset{\text { level }}{P}$ & $\begin{array}{l}\text { Mean fat cell } \\
\text { weight, abdominal } \\
\text { region }\end{array}$ & $\begin{array}{l}\text { Mean fat cell } \\
\text { weight, femoral } \\
\text { region }\end{array}$ & $\underset{\text { level }}{P}$ \\
\hline & \multicolumn{2}{|c|}{$\mu m$} & \multicolumn{4}{|c|}{$\mu g /$ cell } \\
\hline Lean & $83 \pm 3$ & $94 \pm 3$ & $<0.05$ & $0.32 \pm 0.04$ & $0.46 \pm 0.04$ & $<0.05$ \\
\hline Obese & $107 \pm 3$ & $108 \pm 4$ & NS & $0.66 \pm 0.05$ & $0.68 \pm 0.07$ & NS \\
\hline$P$ level & $<0.001$ & $<0.05$ & & $<0.001$ & $<0.05$ & \\
\hline
\end{tabular}

$<0.001)$ than in plasma in all subjects. Furthermore, in the postabsorptive state obese subjects had significantly higher interstitial glycerol levels, both in the abdominal and femoral regions, than lean subjects $(\sim 65 \%$ and $\sim 45 \%$ increase in abdominal and femoral sites, respectively). In the obese group, the interstitial glycerol concentration was significantly higher $(\sim 25 \%)$ in abdominal than in femoral subcutaneous tissue $(P$ $<0.05$ ), whereas no regional differences were seen in the lean group. Fasting plasma FFA and glycerol concentrations were similar in the two groups.

In the postabsorptive state interstitial glycerol levels in the abdominal but not in the femoral region correlated significantly with plasma glycerol (Table IV).

Effect of oral glucose. $2 \mathrm{~h}$ after ingestion of $100 \mathrm{~g}$ of glucose the relative differences in interstitial glycerol concentrations between the obese and lean groups were larger than those seen in the postabsorptive state $(\sim 220 \%$ and $\sim 190 \%$ higher glycerol levels in the abdominal and femoral regions, respectively, see Table III). However, no regional differences were seen. Plasma FFA levels were significantly higher in the obese than in the lean group $(P<0.05$; Fig. 1$)$ after glucose ingestion, whereas the plasma glycerol concentrations were not significantly different $(P<0.1)$.

Fig. 2 depicts the time course for the plasma and interstitial glycerol levels after glucose ingestion. Maximal decline occurred at a similar time point in both groups in the interstitial space as well as in plasma. Higher plasma insulin levels were consistently seen in the obese than in the lean subjects $(89 \pm 18$ and $31 \pm 6 \mathrm{mU} /$ liter at $120 \mathrm{~min}$, respectively; $P<0.05$ ).

The interstitial glycerol concentration in abdominal tissue correlated significantly with the plasma insulin level $120 \mathrm{~min}$ after glucose ingestion $(r 0.846, P<0.002)$ but not in the postabsorptive state $(r 0.490, P<0.1)$. No such correlation was found with the interstitial glycerol concentration in femoral tissue.

In the postabsorptive state the obese group had significantly greater arterial-interstitial glycerol differences ( $\Delta$ glycerol) in the abdominal region compared to both regions in lean subjects $(P<0.05)$. Within the obese group $\Delta$ glycerol in the abdominal region was also higher than that in the femoral site $(P$ $<0.05$; Fig. 3). Furthermore, the obese had an increased $\Delta$ glycerol in the femoral site at 90 and $120 \mathrm{~min}(P<0.05)$ and in the abdominal site at $120 \mathrm{~min}(P<0.05)$ as compared to lean subjects.

$A T B F$. Fig. 4 shows the rate constants for the ${ }^{133} \mathrm{Xe}$ washout. Because an exceedingly high elimination rate was registered in the thigh in one lean subject, indicating intramuscular deposition, the data on this individual were excluded. In the postabsorptive state, ATBF was increased in the abdominal adipose tissue in lean as compared to obese subjects $(P<0.05$; Table III). After the glucose challenge there was a significant increase in ${ }^{133} \mathrm{Xe}$-clearance in both sites in the lean subjects $(P$ $<0.05$ ), whereas the blood flow response to glucose was blunted in the obese. A negative correlation was found between

Table III. ATBF and Subcutaneous Interstitial and Plasma Glycerol before (0 min) and 120 min after an OGTT

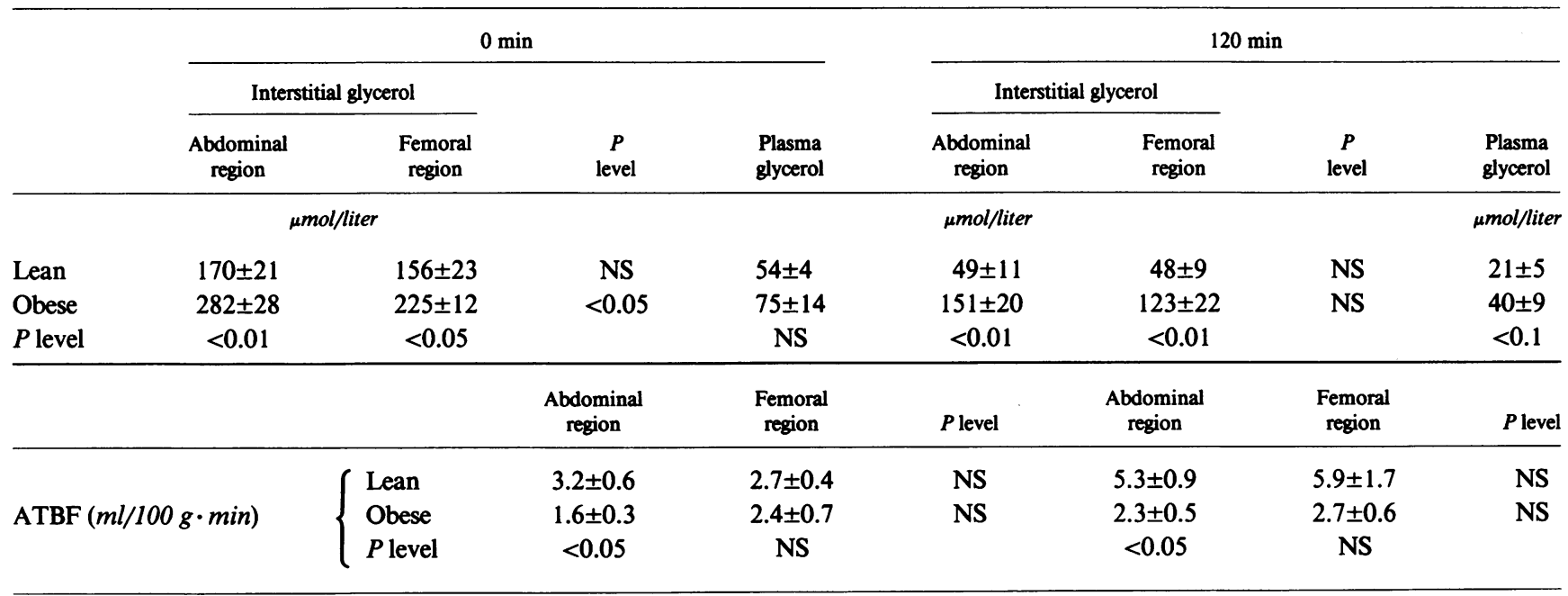

Data are means \pm SE. 
Table IV. Correlations between Cell Size and Various Plasma and Interstitial Concentrations in the Postabsorptive State

\begin{tabular}{|c|c|c|c|c|c|c|c|c|c|}
\hline & \multicolumn{2}{|c|}{ Cell size } & \multicolumn{2}{|c|}{ Interstitial glycerol } & \multirow{3}{*}{$\begin{array}{l}\text { Plasma } \\
\text { glycerol }\end{array}$} & \multirow{2}{*}{\multicolumn{2}{|c|}{$\begin{array}{c}\begin{array}{c}\text { Arterial-interstitial } \\
\text { glycerol difference }\end{array} \\
\text { Region }\end{array}$}} & \multirow{2}{*}{\multicolumn{2}{|c|}{$\begin{array}{l}\text { ATBF } \\
\text { Region }\end{array}$}} \\
\hline & \multicolumn{2}{|c|}{ Region } & \multicolumn{2}{|c|}{ Region } & & & & & \\
\hline & Abdominal & Femoral & Abdominal & Femoral & & Abdominal & Femoral & Abdominal & Femoral \\
\hline \multicolumn{10}{|l|}{ Cell size } \\
\hline \multicolumn{10}{|l|}{ Abdominal region } \\
\hline Femoral region & $r 0.707^{\ddagger}$ & & & & & & & & \\
\hline \multicolumn{10}{|l|}{ Interstitial glycerol } \\
\hline Abdominal region & $r 0.748^{\ddagger}$ & $r 0.504^{*}$ & & & & & & & \\
\hline Femoral region & $r 0.573^{*}$ & NS & $r 0.799^{\S}$ & & & & & & \\
\hline Plasma glycerol & $r 0.616^{*}$ & NS & $r 0.600^{*}$ & NS & & & & & \\
\hline \multicolumn{10}{|c|}{$\begin{array}{l}\text { Arterial-interstitial glycerol } \\
\text { difference }\end{array}$} \\
\hline Abdominal region & $r 0.668^{\ddagger}$ & NS & $r 0.912^{\S}$ & $r 0.884^{\S}$ & NS & & & & \\
\hline Femoral region & NS & NS & NS & $r 0.825^{\S}$ & NS & $r 0.646^{*}$ & & & \\
\hline \multicolumn{10}{|l|}{ ATBF } \\
\hline Abdominal region & $r-0.542^{*}$ & NS & NS & $r-0.521^{*}$ & NS & $r-0.547^{*}$ & NS & & \\
\hline Femoral region & NS & NS & NS & NS & NS & NS & NS & NS & \\
\hline
\end{tabular}

${ }^{*} p<0.05 .{ }^{\ddagger} P<0.005 .{ }^{\$} P<0.0005$.

ATBF and mean fat cell size in the abdominal region (Table IV). ATBF correlated negatively with the abdominal glycerol concentration in obese and lean subjects (Table IV). Furthermore, ATBF in the abdominal site correlated positively with skin temperature in the fasting state $(r 0.622, P<0.05)$ and $2 \mathrm{~h}$ after oral glucose ingestion $(r 0.720, P<0.005)$.

Fig. 5 shows the rate of glycerol release per $100 \mathrm{~g}$ of fat. In the calculations the tissue blood partition coefficient was set to $10 \mathrm{ml} / \mathrm{g}$ and the permeability surface product area to $5 \mathrm{ml} / 100$ $\mathrm{g} \cdot \mathrm{min}$ in mean dilated capillaries in subcutaneous fat (33). No differences in estimated local glycerol release were seen between the groups in either region whether compared in the fasting or postprandial states. The decrease in local glycerol release after oral glucose was significant in all regions $(P$ $<0.05)$.

\section{Discussion}

This study supports and extends our recent observation that the fasting interstitial glycerol concentrations in subcutaneous

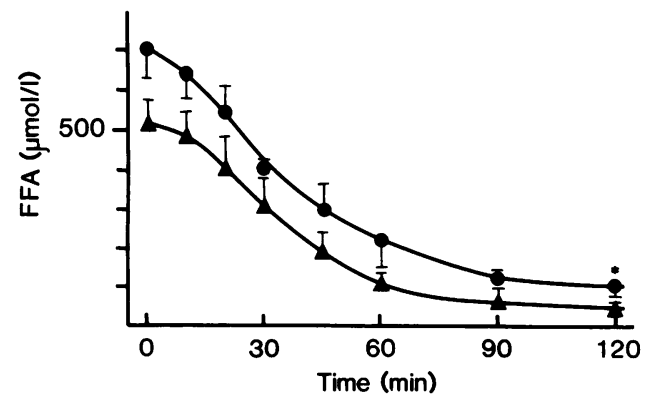

Figure 1. Plasma FFA levels in lean and obese subjects after an overnight's fast and for $2 \mathrm{~h}$ after an OGTT $(100 \mathrm{~g})$. ( $\triangle$ ) Lean subjects. (๑) Obese subjects. Data are means \pm SE. ${ }^{*} P<0.05$ compared to lean subjects. adipose tissue are higher in obese than lean men, and that this increase is further exaggerated in the abdominal region (17). However, only slight differences in arterial plasma glycerol and FFA levels were seen between the groups. Consequently, the difference between the interstitial and arterial glycerol concentrations was significantly greater in the obese subjects, and this difference was particularly pronounced for the abdominal region. Because the obese subjects had significantly higher insulin levels both before and after the glucose load, this finding may be interpreted as resistance to the antilipolytic effect of insulin in obesity. However, the net decrease in interstitial glycerol after oral glucose was similar in obese and lean subjects suggesting an enhanced ongoing lipolysis in the obese, particularly in the abdominal region, combined with a normal antilipolytic response to insulin. A number of studies have shown that the responsiveness to the antilipolytic effect of insulin is normal in isolated fat cells from obese individuals $(12,35,36)$.

The abdominal, but not femoral, interstitial glycerol level correlated significantly with the glycerol concentration in arterial plasma. One interpretation of this finding is that it supports the importance of regional differences in lipid mobilization for whole-body glycerol production. However, it is not clear whether this correlation is due to an increased lipolytic rate in the large abdominal cells or if it is simply due to the existence of a larger adipose tissue mass in obese men. In order to elucidate this, regional glycerol release was estimated by combining microdialysis with blood flow measurements. Interestingly, the ATBF was increased in the abdominal region in lean as compared to obese subjects, whereas no such difference was found for the femoral region.

The increased abdominal ATBF in lean subjects was not due to an erroneous approximation of the tissue/blood partition coefficient to $10 \mathrm{ml} / \mathrm{g}$ in all subjects in that individual estimates of this coefficient, based on the relation between cell size and relative extracellular water content in biopsies, did not alter the results (data not shown). In accordance with this, it has 

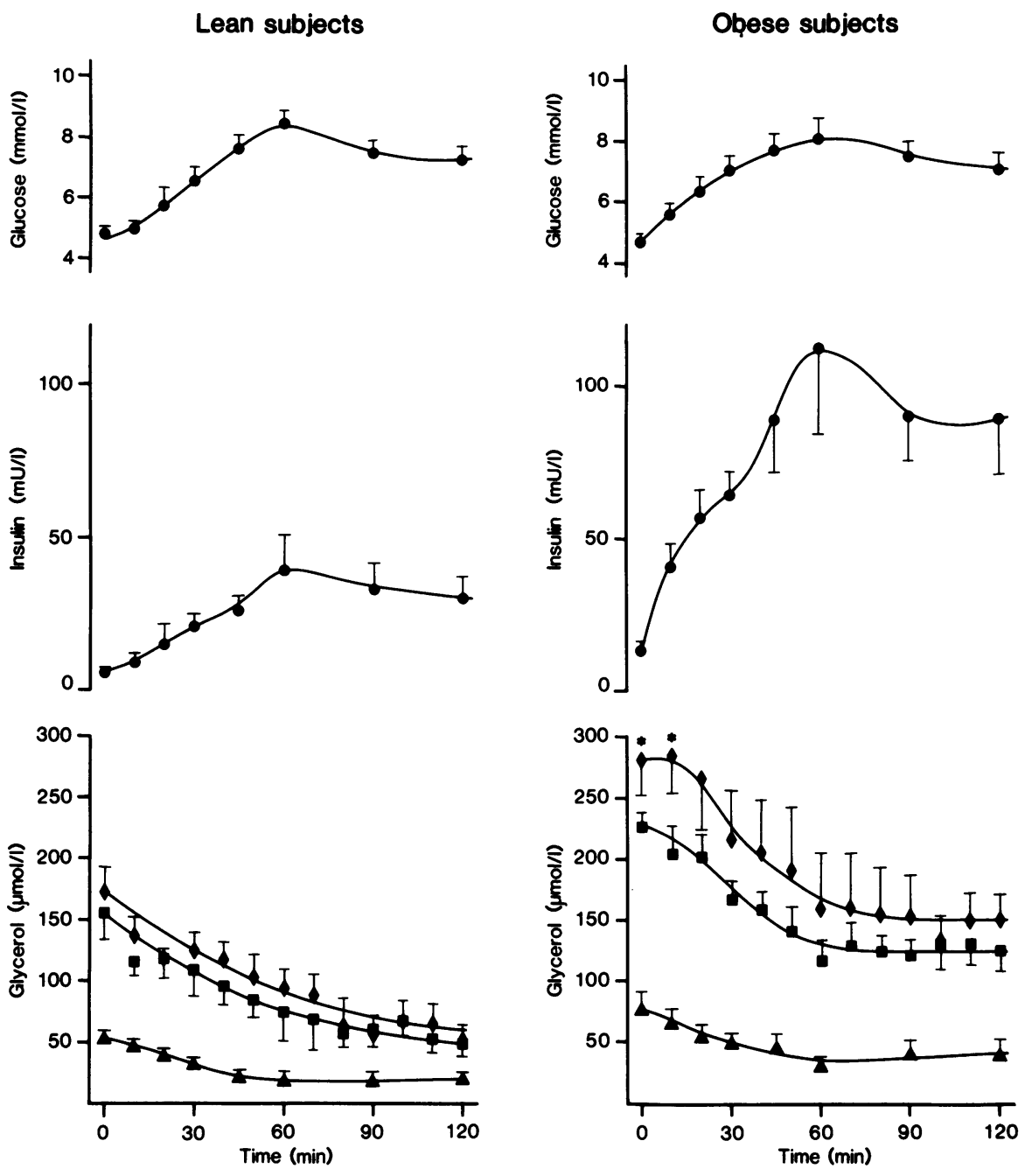

Figure 2. Plasma glucose, insulin, and glycerol levels and interstitial glycerol concentrations before $(0 \mathrm{~min})$ and $2 \mathrm{~h}$ after oral ingestion of $100 \mathrm{~g}$ of glucose in lean and obese subjects. ( $\bullet$ ) Abdominal interstitial glycerol. (घ) Femoral interstitial glycerol. (A) Plasma glycerol. Data are means \pm SE. ${ }^{*} P<0.05$ compared to femoral glycerol levels.

been calculated that the use of a common partition coefficient for the subcutaneous adipose tissue may result in a maximal random error of $\sim 10 \%$ (37).

Glucose ingestion increased ATBF significantly in lean subjects, whereas this was not seen in the obese subjects in either tissue region. As a corollary to this finding, skin temperature increased significantly in the lean but not the obese subjects. Previous studies have shown that ATBF may be decreased in obese subjects $(30,38,39)$ and that this accompanies adipose cell enlargement resulting in a constant blood supply per cell (40). Increased ATBF after oral glucose and a carbohydrate-rich meal have also been reported $(41,42)$. However, the blunted response to glucose in obesity has, to our knowledge, not previously been reported. Interestingly, in a recent report Laakso and co-workers (43) found that the effect of insulin to increase skeletal muscle blood flow was impaired in obese subjects during a hyperinsulinemic, euglycemic clamp. The mechanism for this impairment is unclear but a general defect in peripheral blood flow regulation in obesity seems likely.

Regional differences in ATBF may be of importance for the glycerol release from different fat depots. In this study, glycerol release was estimated according to Fick's principle after recalculating the interstitial glycerol concentrations to those expected to be present in venous capillary plasma. The shortcomings of applying Fick's principle during non-steady-state con- ditions in lean subjects were largely overcome because estimates of both interstitial and venous concentrations could be achieved (44). The data have also been expressed as measures of local glycerol release rather than as absolute production rates. Estimated rates of glycerol release in the postprandial state in the lean subjects were lower than those reported by Coppack et al. (45) who measured glycerol production from the abdominal subcutaneous tissue by cannulating an epigastric vein combined with ATBF. However, activation of the intravascular lipoprotein lipase activity in their study raised the glycerol levels by as much as $30 \%$. When this factor is taken into account the results are comparable (45). The same problem may account for the higher glycerol release per unit adipose tissue weight found in studies where total body glycerol appearance was measured by infusing $\left[{ }^{14} \mathrm{C}\right]$ glycerol in lean (46) and obese (9) subjects. Another factor of importance for wholebody glycerol production is the contribution of the allegedly metabolically active visceral adipose tissue (13).

Glycerol release per $100 \mathrm{~g}$ of subcutaneous tissue was similar in lean and obese subjects and, in addition, no apparent regional differences were found. It is important to note in this context that the interstitial glycerol concentration was increased in obese subjects, particularly in the abdominal region, supporting the view that large adipose cells particularly from abdominal sites have an increased lipolytic rate $(35,47,48)$. 


\section{Lean subjects}

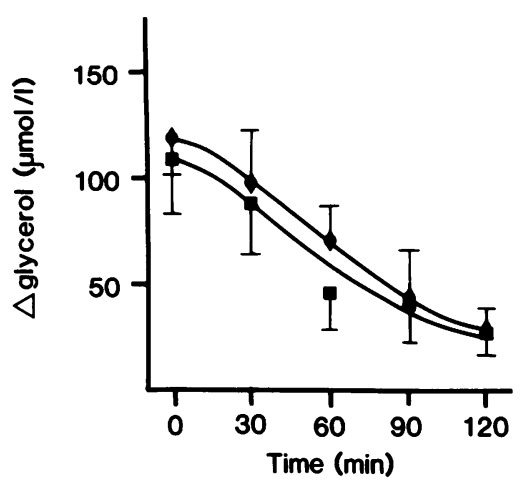

Obese subjects

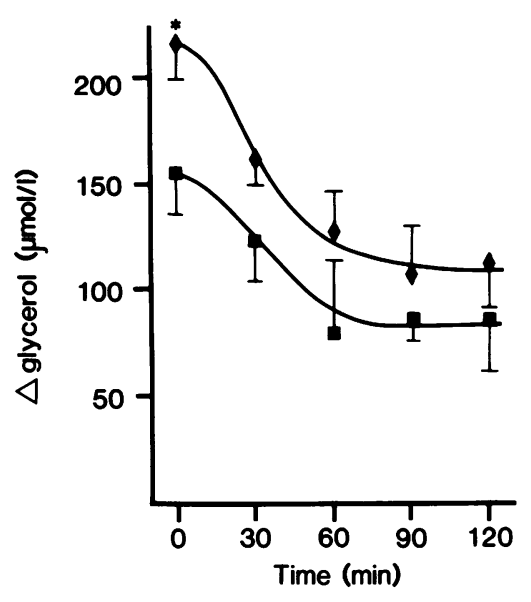

Figure 3. $\Delta$ glycerol, i.e., difference between interstitial glycerol and arterialized venous plasma glycerol in the postabsorptive state and for $2 \mathrm{~h}$ after oral ingestion of $100 \mathrm{~g}$ of glucose in lean and obese subjects. ( $\bullet$ ) Abdominal subcutaneous adipose tissue. (घ) Femoral subcutaneous adipose tissue. Data are means \pm SE. ${ }^{*} P<0.05$ compared to femoral glycerol levels.

However, the lower ATBF in obesity found in the present investigation compensated for the higher lipolytic rate resulting in a "normal" glycerol release from the tissue. The difference in glycerol concentration between interstitial water and arterial plasma also correlated negatively with ATBF (Table IV). Con-

sequently, glycerol release per unit tissue weight is similar in lean and obese subjects, confirming previous in vitro data (35, 49,50 ), whereas the glycerol release per adipose cell is enhanced in large cells (Table IV). Previous findings that large adipose cells have a higher lipolytic rate than small cells in vitro $(35,47,48)$, and that abdominal subcutaneous fat cells have a higher lipolytic rate than those from the leg (12) can thus be confirmed by the current in situ measurements.

When the present findings are expressed as glycerol release per cell, abdominal adipocytes would account for 0.7 and 1.7 $\mathrm{fmol}$ glycerol/min per cell, whereas the release from femoral cells would be 1.1 and $1.5 \mathrm{fmol}$ glycerol/min per cell in lean and obese subjects, respectively. These rates are considerably lower than those reported with isolated human adipocytes in vitro $(35,51)$. A similar discrepancy was noted in a study of canine adipose tissue in situ where the rate of glycerol release was lower than that from adipose tissue in vitro (52). Thus, in vitro studies with isolated adipocytes may give valuable information on lipolytic capacity but the results may not reflect the in vivo situation since a large intracellular to medium FFA gradient is established artificially in vitro and, furthermore, because lipolysis is regulated in vivo by local factors such as blood flow, adenosine (53), lactate (54), FFA (55), prostaglandins (56), partial hydrolysis (8), etc. Finally, it should be emphasized that in the present study we only measured the metabolism of subcutaneous fat and have no information about the intraabdominal depot. Visceral fat cells are smaller than subcutaneous cells but also have a high lipolytic rate (13) and may be of importance for the metabolic aberrations in abdominal obesity (57).

In summary, microdialysis in combination with ATBF gives unique information of adipose tissue metabolism at the cellular level. The present data show that enlarged abdominal fat cells have an increased lipolytic rate. Furthermore, it is demonstrated for the first time in vivo that, owing to a decreased subcutaneous ATBF in obese subjects, the regional rate of glycerol release is similar in lean and obese subjects in two different subcutaneous depots. Thus, total subcutaneous glycerol production is directly proportional to the amount of adipose tissue.
Lean subjects

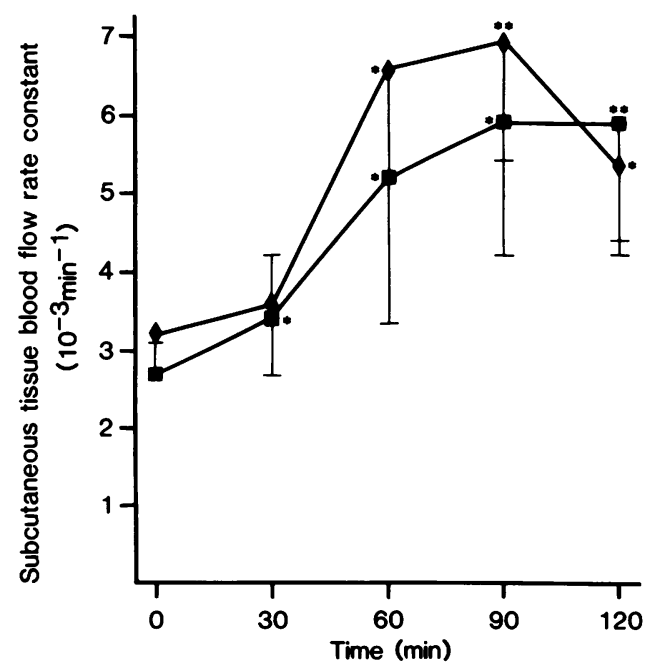

Obese subjects

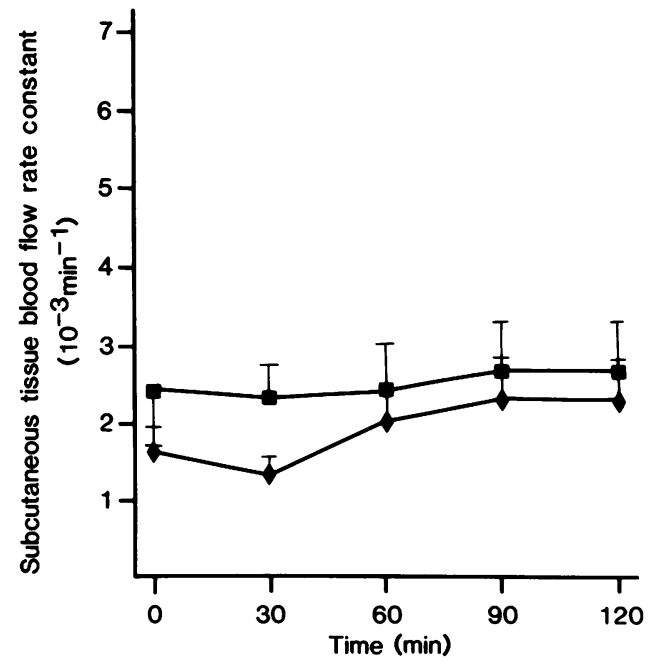

Figure 4. Subcutaneous adipose tissue blood flow rate constant from a ${ }^{133} \mathrm{Xe}$ depot placed $5 \mathrm{~mm}$ under the skin. The rate constant was determined over consecutive 30 min intervals in the postabsorptive state and for $2 \mathrm{~h}$ after an OGTT. Data shown on the ordinate equals estimated ATBF. One observation was missing from the femoral site in the lean subjects $(n=7)$.

$(\bullet)$ Abdominal subcutaneous adipose tissue. (a) Femoral subcutaneous adipose tissue. Data are means \pm SE. ${ }^{*} P$ $<0.05$ and ${ }^{* *} P<0.01$ compared to initial blood flow. 


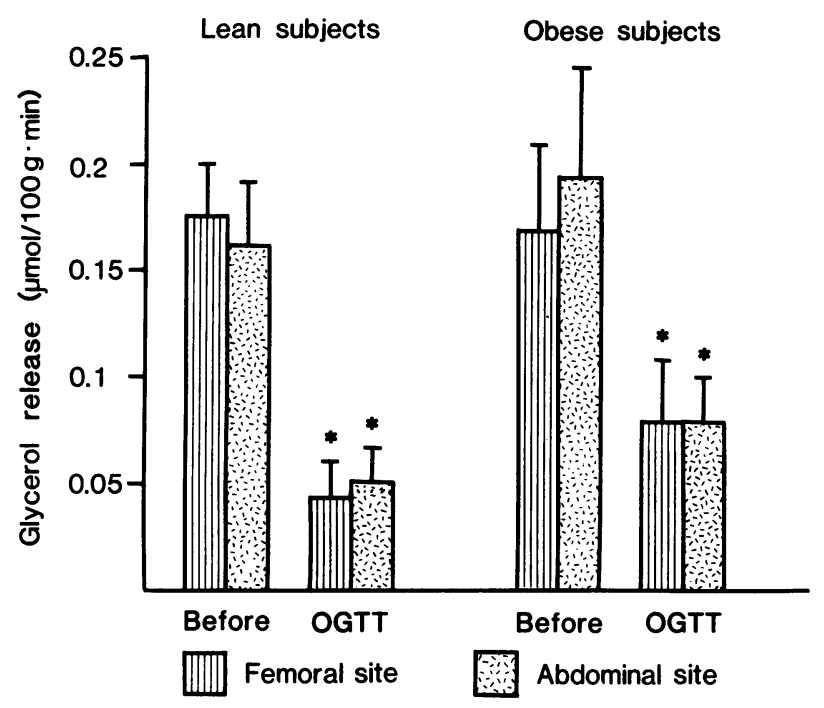

Figure 5. Estimated glycerol release in the postabsorptive state in abdominal and femoral subcutaneous adipose tissue. The lowest estimated rate of release during the OGTT (between 60 and $120 \mathrm{~min}$ ) is shown for the lean and obese subjects. Calculations were made for seven lean subjects in the femoral region. Data are means $\pm \mathrm{SE}{ }^{*} P$ $<0.05$ compared to initial production rates.

\section{Acknowledgments}

The technical assistance by Helle Persson and Vibeke Malmros is gratefully acknowledged. We are grateful to Drs. Jens Bülow and Lene Simonsen, Department of Clinical Physiology, Bispebjerg Hospital, Copenhagen for helping us establish the ${ }^{133} \mathrm{Xe}$-clearance technique. The advice given by Professor Bengt Rippe, Department of Nephrology, University of Lund, is gratefully acknowledged. We are also indepted to Dr. Tom William-Olsson and Professor Lars Sjöström for help in recruiting the obese patients and to Dr. Henning von Schenck for performing the insulin analyses.

Excellent secretarial aid was given by Anna-Lena Dahlgren and Kaisa Torstensson. This study was supported by grants from the Swedish Medical Research Council (B-3506), the Faculty of Medicine at the University of Göteborg, the Swedish Diabetes Association, Svenska Sällskapet för Medicinsk forskning, the Swedish Society of Medicine, Göteborgs Läkaresällskap, The Royal Society of Arts and Sciences in Gothenburg, and "Förenade Liv" Mutual Group Life Insurance Company, Stockholm, Sweden.

\section{References}

1. Vague, J. 1956. The degree of masculine differentiation of obesities, a factor determining predisposition to diabetes, atherosclerosis, gout and uric calculous disease. Am. J. Clin. Nutr. 4:20-34.

2. Kissebah, A. H., N. Videlingum, R. Murray, D. J. Evans, A. J. Hartz, R. K. Kalkhoff, and P. W. Adams. 1982. Relation of body fat distribution to metabolic complications of obesity. J. Clin. Endocrinol. Metab. 54:254-260.

3. Krotkiewski, M., P. Björntorp, L. Sjöström, and U. Smith. 1983. Impact of obesity on metabolism in men and women. Importance of regional adipose tissue distribution. J. Clin. Invest. 72:1150-1162.

4. Reaven, G. M. 1988. Role of insulin resistance in human disease. Diabetes 37:1595-1607.

5. Landin, K., M. Krotkiewski, and U. Smith. 1989. Importance of obesity for the metabolic abnormalities associated with an abdominal fat distribution. $M e$ tab. Clin. Exp. 38:572-576.

6. Lapidus, L., C. Bengtsson, B. Larsson, K. Pennert, E. Rybo, and L. Sjöström. 1984. Distribution of adipose tissue and risk of cardiovascular disease and death: a 12-year follow-up of participants in the population study of women in Gothenburg, Sweden. Br. Med. J. 289:1257-1261.

7. Larsson, B., K. Svärdsudd, L. Welin, L. Wilhelmsen, P. Björntorp, and G.
Tibblin. 1984. Abdominal adipose tissue distribution, obesity, and risk of cardio vascular disease and death: 13 year follow-up of participants in the study of men born in 1913. Br. Med. J. 288:1401-1404.

8. Björntorp, P., H. Bergman, E. Varnauskas, and B. Lindholm. 1969. Lipid mobilization in relation to body composition in man. Metab. Clin. Exp. 18:840 851.

9. Bortz, W. M., P. Paul, A. C. Haff, and W. L. Holmes. 1972. Glycerol turnover and oxidation in man. J. Clin. Invest. 51:1537-1546.

10. Jensen, M. D., M. W. Haymond, R. A. Rizza, P. E. Cryer, and J. M. Miles 1989. Influence of body fat distribution on free fatty acid metabolism in obesity. J. Clin. Invest. 83:1168-1173.

11. Ferrannini, E., E. J. Barrett, S. Bevilacqua, and R. A. DeFronzo. 1983 Effects of fatty acids on glucose production and utilization in man. J. Clin. Invest 72:1737-1747.

12. Smith, U., J. Hammarsten, P. Björntorp, and J. G. Kral. 1979. Regional differences and effect of weight reduction on human fat cell metabolism. Eur. J. Clin. Invest. 9:327-332.

13. Rebuffe-Scrive, M., B. Andersson, L. Olbe, and P. Björntorp. 1989. Metabolism of adipose tissue in intraabdominal depots of non-obese men and women Metab. Clin. Exp. 38:453-458.

14. Svedberg J., P. Björntorp, U. Smith, and P. Lönnroth. 1990. Free-fatty acid inhibition of insulin binding, degradation, and action in isolated rat hepatocytes. Diabetes. 39:570-574.

15. Peiris, A., R. Mueller, G. Smith, M. Struve, and A. Kissebah. 1986. Splanchnic insulin metabolism in obesity. J. Clin. Invest. 78:1648-1657.

16. Strömblad, G., and P. Björntorp. 1986. Reduced hepatic insulin clearance in rats with dietary-induced obesity. Metab. Clin. Exp. 35:323-327.

17. Jansson, P.-A., U. Smith, and P. Lönnroth. 1990. Interstitial glycerol concentration measured by microdialysis in two subcutaneous regions in humans. Am. J. Physiol. 258:E918-E922.

18. Arner, P., E. Kriegholm, P. Engfeldt, and J. Bolinder. 1990. Adrenergic regulation of lipolysis in situ at rest and during exercise. J. Clin. Invest. 85:893898.

19. Jensen, M. D. 1991. Regulation of forearm lipolysis in different types of obesity: in vivo evidence for adipocyte heterogenity. J. Clin. Invest. 87:187-193.

20. Lönnroth, P., P.-A. Jansson, and U. Smith. 1987. A microdialysis method allowing characterization of intercellular water space in humans. Am. J. Physiol. 253:E228-E231

21. Belfrage, E., P. Hjemdahl, and B. B. Fredholm. 1979. Metabolic effects of blood flow restriction in adipose tissue. Acta Physiol. Scand. 105:222-227.

22. Hirsch, J., S. K. Fried, N. K. Edens, and R. L. Leibel. 1989. The fat cell. Med. Clin. North Am. 73:83-96.

23. Bülow, J., M. Hansen, and J. Maadsen. 1976. Variation in human subcutaneous adipose tissue blood flow (ATBF). Acta Physiol. Scand. 96:30A-31A.

24. Crandall, D. L., B. M. Goldstein, F. Huggins, and P. Cervoni. 1984 Adipocyte blood flow: influence of age, anatomic location, and dietary manipulation. Am. J. Physiol. 247:R46-R51.

25. National Diabetes Data Group. 1979. Classification and diagnosis of diabetes mellitus and other categories of glucose intolerance. Diabetes. 28:10391057.

26. Attvall, S. 1989. Insulin-antagonistic effects of pulsatile and continuous glucagon infusions in man in comparison with the effect of adrenaline. Ph.D. thesis. University of Göteborg, Sweden.

27. Jansson, P.-A., U. Smith, and P. Lönnroth. 1990. Evidence for lactate production by human adipose tissue. Diabetologia. 33:253-256.

28. Smith, U., L. Sjöström, and P. Björntorp. 1972. Comparison of two methods for determining human adipose cell size. J. Lipid Res. 13:822-824.

29. Lukaski, H. C., W. W. Bolonchuk, C. B. Hall, and W. A. Siders. 1986. Validation of a tetrapolar bioelectrical impedance method to assess human body composition. J. Appl. Physiol. 60:1327-1332.

30. Larsen, O. A., N. A. Lassen, and F. Quaade. 1966. Blood flow through human adipose tissue determined with radioactive Xenon. Acta Physiol. Scand. 66:337-345.

31. Bradley, D. C., and H. R. Kaslow. 1989. Radiometric assays for glycerol, glucose, and glycogen. Anal. Biochem. 180:11-16.

32. Lassen, N. A. 1967. Capillary diffusion capacity of sodium studied by the clearances of Na-24 and Xe-133 from hyperemic skeletal muscle in man. Scand. J. Clin. Lab. Invest. 19(Suppl. 99):24-26.

33. Paaske, W. P. 1977. Absence of restricted diffusion in adipose tissue capillaries. Acta Physiol. Scand. 100:430-436.

34. Bradley, J. V. 1968. Distribution-free Statistical Tests. Prentice-Hall, Inc., Englewood Cliffs, NJ. 68-86.

35. Jacobsson, B., and U. Smith. 1972. Effect of cell size on lipolysis and antilipolytic action of insulin in human fat cells. J. Lipid Res. 13:651-656.

36. Arner, P., J. Bolinder, P. Engfeldt, and J. Östman. 1981. The antilipolytic effect of insulin in human adipose tissue in obesity, diabetes mellitus, hyperinsulinemia and starvation. Metab. Clin. Exp. 30:753-760. 
37. Nielsen, S. L. 1972. Adipose tissue blood flow determined by the washout of locally injected ${ }^{133}$ Xenon. Scand. J. Clin. Lab. Invest. 29:31-36.

38. Nielsen, S. L., and O. A. Larsen. 1973. Relationship of subcutaneous adipose tissue blood flow to thickness of subcutaneous tissue and total body fat mass. Scand. J. Clin. Lab. Invest. 31:383-388.

39. Lesser, G. T., and S. Deutsch. 1967. Measurement of adipose tissue blood flow and perfusion in man by uptake of ${ }^{85} \mathrm{Kr}$. J. Appl. Physiol. 23:621-630.

40. DiGirolamo, M., N. S. Skinner, H. G. Hanley, and R. G. Sachs. 1971. Relationship of adipose tissue blood flow to fat cell size and number. Am. J. Physiol. 220:932-937.

41. Bülow, J., A. Astrup, N. J. Christensen, and J. Kastrup. 1987. Blood flow in skin, subcutaneous adipose tissue and skeletal muscle in the forearm of normal man during an oral glucose load. Acta Physiol. Scand. 130:657-661.

42. Simonsen, L., Bülow J., Astrup, A., J. Madsen, and N. J. Christensen 1990. Diet-induced changes in subcutaneous adipose tissue blood flow in man effect of $\beta$-adrenoceptor inhibition. Acta Physiol. Scand. 139:341-346.

43. Laakso, M., S. V. Edelman, G. Brechtel, and A. D. Baron. 1990. Decreased effect of insulin to stimulate skeletal muscle blood flow in obese man: a novel mechanism for insulin resistance. J. Clin. Invest. 85:1844-1852.

44. Zierler, K. L. 1961. Theory of the use of arteriovenous concentration differences for measuring metabolism in steady and non-steady states. J. Clin. Invest. 40:2111-2125.

45. Coppack, S. W., R. M. Fisher, G. F. Gibbons, S. M. Humphreys, M. J. McDonough, J. L. Potts, and K. N. Frayn. 1990. Postprandial substrate deposition in human forearm and adipose tissues in vivo. Clin. Sci. 79:339-348.

46. Nurihan, N., P. J. Campbell, F. P. Kennedy, J. M. Miles, and J. E. Gerich. 1986. Insulin dose-response characteristics for suppression of glycerol release and conversion to glucose in humans. Diabetes. 35:1326-1331.
47. Björntorp, P., and L. Sjöström. 1972. The composition and metabolism in vitro of adipose tissue fat cells of different sizes. Eur. J. Clin. Invest. 2:78-84.

48. DiGirolamo, M., M. D. Howe, J. Esposito, L. Thurman, and J. L. Owens. 1974. Metabolic patterns and insulin responsiveness of enlarging fat cells. J. Lipid Res. 15:332-338.

49. James, R. C., T. W. Burns, and R. Chase. 1971. Lipolysis in human adipose tissue cells: Influence of donor factors. J. Lab. Clin. Med. 77:254-266.

50. Gries, F. A., M. Berger, M. Neumann, H. Preiss, H. Liebermeister, C. Hesse-Wortmann, and K. Jahnke. 1972. Effects of norepinephrine, theophylline and dibuturyl cyclic AMP on in vitro lipolysis of human adipose tissue in obesity. Diabetologia. 8:75-83.

51. Lillioja, S., J. Foley, C. Bogardus, D. Mott, and B. V. Howard. 1986. Free fatty acid metabolism and obesity in man: In vivo in vitro comparisons. Metab. Clin. Exp. 35:505-514.

52. Fredholm, B. B., and J. Karlsson. 1970. Metabolic effects of prolonged sympathetic nerve stimulation in canine subcutaneous adipose tissue. Acta Physiol. Scand. 80:567-576.

53. Lönnroth, P., P.-A. Jansson, B. B. Fredholm, and U. Smith. 1989. Microdialysis of intercellular adenosine concentrations in subcutaneous tissue in humans. Am. J. Physiol. 256:E250-E255.

54. Fredholm, B. B. 1971. The effect of lactate in canine subcutaneous adipose tissue in situ. Acta Physiol. Scand. 81:110-123.

55. Burns, T. W., P. E. Langley, B. E. Terry, and G. A. Robinson. 1978. The role of free fatty acids in the regulation of lipolysis by human adipose tissue cells. Metab. Clin. Exp. 27:1755-1762.

56. Kather, H., and B. Simon. 1979. Biphasic effects of prostaglandin $E_{2}$ on human fat cell adenylate cyclase. J. Clin. Invest. 64:609-612.

57. Björntorp, P. 1990. "Portal" adipose tissue as a generator of risk factors for cardiovascular disease and diabetes. Arteriosclerosis. 10:493-496. 